\title{
New York in Salman Rushdie's Fury
}

Pushpa Raj Acharya

\section{https://doi.org/10.3126/litstud v29i01.39612}

\begin{abstract}
Postcolonial and diasporic novels, such as Salman Rushdie's Fury, explore the interconnections between the global cities and human mobility. Bodily as well as other physical rhythms create affects, which in turn shape rhythm of the urban spaces. New York in such fictional works appears as an exploding, spasmodic city that renews itself with renovations and destruction.
\end{abstract}

In 1980s when de Michel de Certeau looks at Manhattan from the top floor of one of the tallest buildings of New York possibly before taking a walk on the streets, he sees the elevation of the territory on the horizontal level and a "wave" of skyscrapers in "agitation" in the vertical level (91). He notices that the city's textures have the "extremes" and "excesses" of "ambition and degradation," or of "expenditure and production" (91). Manhattan rolls with convulsions, "paroxysmal" moves, and "irruptions" (91). This Manhattan, unlike the celebratory free land of Walt Whitman's "Mannahatta" or "Crossing Brooklyn Ferry," ${ }^{1}$ stands as "a universe that is constantly exploding" (91). In de Certeau's Manhattan, an extreme sense of explosion and agitation arises from the constant reinvention, from the frenzied dance of the capitalistic mode of production and expenditure, and from the city's achievements and failures. Indeed, the tension surfaces from a clash between the institutional, administrative desires and designs to map the city while an individual's everyday practices of walking in the city resist such prescriptions. One may be tempted to compare it with Andrey Bely's account of Petersburg that calls the titular Russian city a symbol of explosion at the cusp of a regime change. One may also wonder whether this sense of paroxysm has foreshadowed the explosion of the tallest towers of New York on September 11, 2001 that began a new cycle of global wars connecting New York with many other "Third World" cities including one small Pakistani town of Abbottabad. ${ }^{2}$

Commenting on the New York-Abbottabad connection, Vassilena Parashkevova argues, in Salman Rushdie's Cities, that the "dynamic intersections of colonial, postcolonial and global contexts" occur to contaminate each other and to reconfigure the urban spaces (10). The cities exist in networks and in constant interrelations, or in what Doreen Massey calls "happenstance

1 Whitman's tone in both poems is mostly celebratory as he goes on listing what he sees in Manhattan. However, in the "Crossing Brooklyn Ferry" he is overwhelmed by questions in his mind while he goes for a walk. This questioning when he takes a walk in the city is perhaps the moment when a slight sense of agitation begins: "I too walk' $d$ the streets of Manhattan island, and bathed in the waters around it, / I too felt the curious abrupt questionings stir within me, / In the day among crowds of people sometimes they came upon me, / In my walks home late at night or as I lay in my bed they came upon me, / I too had been struck from the float forever held in solution..." (stanza 5).

2 A US army operation in May 2011 killed Osama Bin Laden, the mastermind of the 9/11 attacks and head of al-Qaeda, in Abbottabad, northern Pakistan. 
positionings-in-relation-to-each-other" (116). Summarizing Massey's argument, Tim Cresswell defines place as "process," as "defined by outside," as "site of multiple identities and histories," and as unique because of "its interactions" (74). The insights from Massey, Cressell, and de Certeau remind us of the connections between city and everyday life, and between cities and movements.

This paper focuses on diasporic characters' everyday life in New York City and their peripatetic and phenomenological experiences. In particular, the paper studies Malik Solanka's walk in Salman Rushdie's Fury (2001), which portrays New York as a space of constant explosion and of agitation, ambition, affection, rage, and fear, which are parts of rhythm or its breakdown. These affects are also part of what Henri Lefebvre refers to as rhythmanalysis that keeps peripatetic experience at the center, with a focus on movements, repetitions, and differences inside or outside body. Salman Rushdie's characters walk in the cities and travel between the cities to understand their emotions and their connections to space. In Fury, Solanka has already taken the flights from Bombay to London to New York, but he returns to the former through memories and phone-calls. In New York, Solanka walks endlessly as the rhythm of intense fury keeps him restless, and he hopes that the city can "devour" his fury because of its chaotic and furious nature. Solanka's self-treatment-homeopathic in nature - is to put himself in this chaotic, furious city to cure his intense rage because New York is a constantly exploding paroxysmal universe.

Other fictional travellers from South Asia also share Solanka's sense of mobility and interconnections among cities, although their moods vary significantly. In Kiran Desai's The Inheritance of Loss (2006), a Nepalispeaking cook comes from a small North Indian town of Darjeeling and stays in the US illegally. New York, for him, is as a space of hope. In Prajwal Parajuly's The Gurkha's Daughter (2013), another immigrant character from the same region and ethnic background finds an intimacy of a Nepali-speaking woman, who can help him stay in the US legally. Desai's and Parajuly's diaspora characters imbricate New York with the local politics of their home cities from where they have travelled. This imbrication separates the diapora writers from American novelists like Thomas Pynchon and Don DeLillo. Pynchon's and DeLillo's characters find New York a puzzle to be solved because of its position in the world. Pynchon's novel Bleeding Edge (2013) opens with a walk. Its female protagonist is taking her two children to their school in New York some time before the 9/11 attacks. She enters a complex truth-seeking mission about the suspicious financial transactions in the labyrinth of cyber world that starts foreshadowing the 9/11 attacks. After the attacks, her children walk to school without her, while she is still unable to solve all the dimensions of the puzzle. In Don DeLillo's The Falling Man (2007), the protagonist who is a survivor of the 9/11 walks in the streets of New York like a ghost in order to deal with his trauma. Fury is also about one man's desire to overcome his rage in New York just before the 9/11 attacks, but he carries the burden of memory that comes from other cities.

Salman Rushdie's Fury is rather a novel about rhythm of fury. Caught in the repetitive rhythm, Professor Malik Solanka, a 55-year-old retired historian of ideas, irascible dollmaker, rents a spacious sublet at Upper West Side of Manhattan. Solanka, who has left his job at Cambridge University, once created 
wooden dolls as hobby but they are the characters of a popular TV show and franchise. The dolls have given him fame, wealth, and fury. Once in a feverish furious state, he finds himself approaching to his sleeping wife, Eleanor, and son, Asmaan, with a knife, and so he leaves them in London and flies to New York. He takes long walks in New York, goes for all-night excursions, or drinks so much that in some mornings he is lying on the streets or on others, in his apartment.

Jumping into chaos of a mega city, Solanka wants to "to erase himself. To be free of attachment" (Rushdie 44). One of the places he visits to calm down is the Central Park: "On Central Park West the horse-drawn carriages moved up and down. The jingling of the bells on the harnesses sounded like cash in hand" (6). The Central park has rhythm, energy, and movement: "They sat on a bench near the pond, and all around them dog walkers were colliding with trees, Tai Chi practitioners lost their balance, rollerbladers smashed into one another, and people out strolling just walked right into the pond as if they'd forgotten it was there. Neela Mahendra gave no sign of noticing any of this. A man walked past with an ice cream cone [...] (Rushdie 149). Solanka observes the movement and rhythms of people and objects in the Park.

Rhythm is in the everyday life of cities and in our movement through space. One can observe several themes like "the thing, the object, life in the urban or rural environment, the role of media, political discipline, and the notion of dressage, and music among others - and [rethink] them through the notion of rhythm. The question of the body, and in particular the body under capitalism, is a recurrent and indeed central topic" (Elden viii). The body remains at the center in this analysis as it has both social and biological rhythm. To observe the rhythm in the city is to study the "actions and behaviours of bodies that inhabit the space of the city" as well as to analyze "the performative tensions produced by various uses, occupations and contestations of urban spaces" (Whybrow 1). Solanka does so at the park or in the streets, which become dark and bizarre at times.

Rhythm, whether dark or bright, is a category that can reveal an interrelationship among time, space, and energy. Lefebvre describes rhythm as a repetition of movements or situation in linear or cyclic processes or even birth, growth, and decline. It may be psychological and physiological, told and untold, or remembered and forgotten. A written text may have verbal rhythm and expression, and as in music, rhythm comes from "long and short times, recurring in a recognizable way, stops, silence, blanks, resumptions, and intervals, in accordance with regularity, must appear in a movement. Rhythm therefore brings with it a differentiated time, a qualified duration. The same can be said of repetitions, ruptures and resumptions" (Lefebvre 78). Rhythm emerges from the patterns, repetitions, gaps, and differences.

Fury is one such powerful affect that creates Solanka's physiological, psychosocial, and social rhythm. Fury is, at the same time, the rhythm of New York City. Fury in the city operates in existential as well as geo-political levels. Fury comes from the depths of being, and one can try to define "what fury is" from different perspectives. For Solanka, at least, life itself is "fury [. . . ] sexual, Oedipal, political, magical, brutal [. . ]" and it takes one to both zenith and nadir (Rushdie 30).

From Fury, comes creation, inspiration, originality, passion, but 
also violence, pain, pure unafraid destruction, the giving and receiving of blows from which we never recover. The Furies pursue us; Shiva dances his furious dance to create and also to destroy. But never mind about gods! Sara ranting at him represented the human spirit in its purest, least socialized form. This is what we are, what we civilize ourselves to disguisethe terrifying human animal in us, the exalted, transcendent, self-destructive, untrammeled lord of creation. We raise each other to the heights of joy. We tear each other limb from fucking limb. (Rushdie 31)

Solanka thinks that fury has both "beauty and vengeful wrath" because Homar calls Furies Aphrodite's sister (Rushdie 251). Furies or Erinyes are three autochthonous Greek goddesses, and Virgil identifies them as Alecto, the "unceasing," Magaera, the "grudging," and Tisiphone, "the vengeful destruction." As one critic, R. Chakkarvarthy notes, they chase the culprit endlessly, "without rest or pause, from city to city and from country to country" (Rushdie 172). Solanka reasons that he is a victim of Athenian Furies.

But in the contemporary world, Athenian Furies, Solanka acknowledges, take human body. Solanka thinks that he is pursued by these Furies whose "siblings included Terror, Strife, Lies, Vengeance, Intemperance, Altercation, Fear, and Battle" and who "less regarded, were hungrier, wilder, casting their nets more widely ... [f]rom New York to Lilliput-Blefuscu there was no escape from the beating of their wings" (Rushdie 251). Towards the end of the novel, three women in his New York life appear in his bedroom and unleash their wrath. They manifest the invisible fury, which he had been carrying. He is in bed with Neela-his new girlfriend, when two other women, Mila and Eleanor, enter his room. All three call him betrayer and inconsiderate, upon which he hides his face in a pillow and thinks that the Furies have overtaken those women who were once benevolent to him.

Yet, Solanka is not the only one. On the Tenth Avenue, he finds a taxi driver called Ali Majnu venting out his anger against New York: "Islam will cleanse this street of godless motherfucker bad drivers" (Rushdie 65). Solanka relates it with his own experiences and understands why the driver is furious and thinks of the Middle East peace process:

An outgoing American president, hungry for a breakthrough to buff up his tarnished legacy, was urging [Ehud] Barak and [Yasser] Arafat to a Camp David summit conference, Tenth Avenue was perhaps being blamed for the continued sufferings of Palestine. Beloved [Majnu] Ali was Indian or Pakistani, but, no doubt out of some misguided collectivist spirit of paranoiac pan-Islamic solidarity, he blamed all New York road users for the tribulations of the Muslim world. (Rushdie 66)

When Ali realizes that Solanka can understand Urdu - the language he is speaking - he changes the tone and denies that he was even swearing. Solanka says to himself, "words are not deeds.... Though words can become deeds. If said in the right place and at the right time, they can move mountains and change the world" (Rushdie 66). New York experienced the terror attack soon after the book was released in 2001 .

The taxi-driver's fury comes from his geo-political connections, as 
Solanka explains that the relationship between America and the rest of the world is almost sadistic and masochistic. One insults, and the other falls in love with the one who has insulted: "America insulted the rest of the planet, thought Malik Solanka in his old-fashioned way, by treating such bounty with the shouldershrugging casualness of the inequitably wealthy. But New York in this time of plenty had become the object and goal of the world's concupiscence and lust, and the "insult" only made the rest of the planet more desirous than ever" (6). New York's seduction lies in this insult to the world because New York has the bounty and the rest of the world does not have. One may remember Slavoj Žižek's interpretation of envy and violence here to understand this phenomenon. Envy, Žižek argues, is not the result of the Other's possession of the prized object but the other's enjoyment of the object. The true aim then is "to destroy the Other's ability/capacity to enjoy the object. So we see the envy needs to be placed within the triad of envy, thrift and melancholy, the three forms of not being able to enjoy the object and, of course, reflexively enjoying that very impossibility" (Žižek 77). As Žižek explains, there is a desire to possess or destroy the jouissance of the other. The experience of fury in New York is this tension between envy and violence and between domination and seduction. As the affects of fury have engulfed Solanka and the city, the repetitive walk in the city unravels different levels of agitations in the city and self.

However, the comment on the purpose of his walk opens to us an important dimension that will be an imperative for theorizing a diasporic character's relationship with New York:

He didn't feel intruded upon amid these multitudes; to the contrary. There was a satisfying anonymity in the crowds, an absence of intrusion. Nobody here was interested in his mysteries. Everyone was here to lose themselves. Such was the unarticulated magic of the masses, and these days losing himself was just about Professor Solanka's only purpose in life. (Rushdie 7)

Solanka has been walking because he finds anonymity in New York. By losing himself in the crowd as an anonymous entity, this character wants to find a sense of comfort. In the times of surveillance and, at times, racial profiling, this sense of anonymity becomes important to diasporic characters. Solanka in Rushdie's Fury connects the streets of Manhattan with his walk in an effort to pacify the spewing rage of capitalism, global violence, and human condition.

\section{Works Cited}

Bely, Andrey. Petersburg. Trans. J D. Elsworth. London: Pushkin Press, 2010. Print.

Chakkaravarthy, R. "Seized by 'Furies': A study of Salman Rushdie's Fury." Language In India (July 2013): 171-177. Web. Mar. 30, 2015.

Cresswell, Tim. Place: A Short Introduction. Oxford: Blackwell, 2004. Print.

de Certeau, Michel. "Walking in the City." The Practice of Everday Life. Trans.

Steven Rendall. Berkeley: U of California P, 1983. 91-114. Print.

DeLillo, Don. Falling Man: A Novel. New York: Scribner, 2007. Print.

Desai, Kiran. The Inheritance of Loss. Toronto: Penguin Canada, 2006. Print.

Elden, Stuart. "Rhythmanalysis: An Introduction." Rhythmanalysis: Space, Time 
and Everyday Life. Henri Lefebvre. Trans. Elden Stuart and Gerald Moore. London: Continuum, 2004. vii-xv. Print.

Lefebvre, Henri. Rhythmanalysis: Space, Time and Everyday Life. Trans. Elden Stuart and Gerald Moore. London: Continuum, 2004. Print.

Massey, Doreen. For Space. London: Sage, 2005. Print.

Parajuly, Prajwal. The Gurkha's Daughter. London : Quercus, 2013

Parashkevova, Vassilena. Salman Rushdie's Cities: Reconfigurational Politics and the Contemporary Urban Imagination. London: Continuum, 2012. Print.

Pynchon, Thomas. The Bleeding Edge. New York: Penguin, 2013. Print.

Rushdie, Salman. Fury. London: Jonathan Cape, 2001. Print.

Whitman, Walt. "Crossing Brooklyn Ferry." Poetry Foundation. Apr 18, 2015. Web.

Whybrow, Nicolas, ed. "Writing Performing Cities: An Introduction." Performing Cities. New York: Palgrave Macmillan, 2014. 1-18. Web.

Žižek, Slavoj. Violence: Six Sideways Reflections. London: Profile Books, 2008. 